\title{
A "BELA MORTE"
}

Laurie Laufer

\author{
Psicanalista. \\ Professor, \\ Universidade de \\ Paris 7 Diderot, \\ CRPMS EA 3522, \\ Paris Sorbonne Cité. \\ Tradução: Roberta \\ Bertone
}

RESUMO: É com uma realidade encoberta, com o pudor e com a vergonha que se articula a visão do corpo do morto; a problemática do fantasma ligado ao morto. Se a sexualidade parece-nos, atualmente, menos velada do que na época clássica, a morte, por sua vez, tornou-se tabu e deslocou-se para a esfera privada, para o território da intimidade psicológica, o que Phillipe Ariès denomina "a morte tornada selvagem". Na descrição que Flaubert faz do falecimento de Ema, em Madame Bovary, as imagens da morte e da decomposição do corpo morto mantêm vivas uma iconografia recalcada, "aureolada". O processo de censura contra o livro é emblemático da repressão da sociedade sobre a representação da morte.

Palavras-chave: Morte, visibilidade, censura, catarse, fantasia.

ABSTRACT: The "beautiful death". It is in the hidden visibility, in the modesty and in the shame that the issue of viewing the body of the dead takes shape, going towards the phantasmal aspect (aspect of fantasy) linked to the dead. If sexuality seems less veiled as compared to the classical era, death in itself has become a taboo and withdraws itself into the private sphere, into a psychological intimacy, what Ariès calls "the barbarization of death". Concerning Flaubert, writing about the death of Emma Bovary, the imagery of the body's decomposition and of death creates a repressed, "halo-ed" imagery. The censor process against Madame Bovary is, in this respect, symbolic of society's repression of the representation of death.

Keywords: The dead, visibility, censure, catharsis, fantasy. 
"O rosto no momento da morte: cinza, absolutamente cinza. Eu nunca tinha visto aquilo, e no entanto, foram numerosos os mortos ao meu redor. Como era inesperado e surpreendente, esse rosto cinza, mais cinza!"

(Fala de uma paciente)

드 com uma realidade encoberta, com o pudor e com a vergonha que se articula a visão do corpo morto; a problemática do fantasma ligado ao morto. É nesta perspectiva que a morte do objeto amado pode nos incitar a explorar o arcaico e o primitivo. O surgimento da dor está ligado à perda do objeto, ao que ele era, e à maneira como ele estava inscrito na vida infantil do enlutado. Então, o que perde o enlutado? A possibilidade da realização de seus desejos ligados aos fantasmas sexuais infantis não estaria no centro da questão que articula fantasma, luto e desejo? A experiência de ver é uma das que se encontra no coração da vivência infantil: não se diz que “a curiosidade é um vil defeito”? A fórmula produz o fantasma do que há para ser visto, daquilo que no corpo é o mais exposto: sua relação com a morte e com o sexo.

Esta visibilidade da morte, do corpo do morto, faz parte da "mortalidade da morte". A morte é mortal porque é barulhenta, visível, porque está em movimento, porque fabrica fantasmas. A imortalidade da morte a torna mortífera. Ora, a doença do luto é uma crença na imortalidade, num corpo imortal. O melancólico é imortal porque não acredita no que sabe, não brinca com seu saber. Quando se coloca a questão do "porquê da morte" ele se esvazia, consome-se querendo respondê-la. A questão esvaziada da sua função de enigma, repetida à exaustão, abre espaço para a melancolia.

Atualmente, a morte e a visibilidade do corpo morto não existem mais. Desde que a morte teve seu sentido "invertido”, passando a ser dissimulada, encoberta, rechaçada, asseptizada, tudo se passa como se sua fábrica de produzir fantasmas estivesse inativa.

Isso não quer dizer que não vejamos mais a morte: as imagens banalizando valas, mortes violentas, assassinatos e atentados desfilam antes e depois das manchetes esportivas e meteorológicas, mas a linguagem e o espaço de construção fantasmática estão suprimidos: não falamos mais da morte, ela nos é projetada, e a imagem que vem do exterior imobiliza tanto a palavra quanto o fantasma. A imagem sidera, destrói o movimento do visível.

Assim, a obra de Geoffroy Gorer, Pornographie de la mort (1965) é esclarecedora. A ascensão da burguesia e a liberação sexual parecem estar na origem de uma mudança de tabus. Se a sexualidade parece-nos, atualmente, menos velada do que na época clássica, a morte, por sua vez, tornou-se tabu e deslocou-se para a esfera privada, para o território da intimidade psicológica, o que Phillipe Ariès 
denomina "a morte tornada selvagem". O luto torna-se um assunto pessoal a ser tratado solitariamente, uma "massa a dois" entre o morto e o sobrevivente, como se o terceiro (palavra, coletivo, comunidade) tivesse sido excluído dessa relação dual.

É esse deslocamento de sentido que Gorer analisa ao desenvolver o argumento de que, há 200 anos, nossa relação com as três experiências humanas fundamentais, a saber, a copulação, o nascimento e a morte, eram desprovidas de mistério:

“as crianças eram convidadas a pensar sobre a morte, sobre sua própria morte, e aos instrutivos e premonitórios sepultamentos alheios. Durante o século XIX, quando a taxa de mortalidade era elevada, raros foram os que não testemunharam, ao menos uma vez, uma verdadeira agonia, ou que não tenham participado de uma cerimônia fúnebre. Os funerais eram ocasiões de grande ostentação, tanto na classe operária quanto na classe média e na aristocracia. Os cemitérios eram o centro de cada velha aldeia e os que se localizavam em cidades tinham, em geral, uma posição privilegiada. Foi muito tarde, no século XIX, que a execução de criminosos deixou de ser, ao mesmo tempo, um divertimento e uma advertência pública." (GORER, 1965, p.22)

O espetáculo da morte era o acontecimento que possibilitava olhar para a morte, para o corpo do morto, e, pela visão do irrepresentável, permitia uma abertura e um jogo com a morte em si mesma. Ver é necessário para criar um mundo imaginário, e para não ficar preso a uma só imagem, o que seria uma paralisação da vida psíquica. Uma criança que não pode assistir ao enterro de seus pais, a quem a participação no funeral é interditada, fica presa a uma imagem: o que é que estão me proibindo? O irrepresentável continua, assim, irrepresentável e pode tornar-se inominável e impensável. Que formas adquirem, na vida psíquica, o inominável, o impensável e o irrepresentável?

Gorer constata uma mudança que ocorre no século XX: "no momento em que se começa a poder falar do ato sexual, particularmente nas sociedades anglo-saxônicas, torna-se cada vez mais chocante falar da morte como fenômeno natural" (ibidem) e Ariès comenta:

“Os processos naturais de putrefação e de decomposição tornaram-se repugnantes,
tanto quanto os processos naturais do parto e da copulação o eram há um século
atrás. O interesse por esses fenômenos era mórbido e doentio, ao ponto de ser
desaprovado para todos e punido para os jovens. Nossos avós aprenderam que os
bebês eram encontrados sob as folhas dos pés de groselha ou de repolho; nossos
filhos estão aprendendo, provavelmente, que os que 'partiram' tornaram-se flores ou 
repousam em agradáveis jardins. Os horrores são implacavelmente camuflados; a arte dos embalsamadores é a da negação total.” (ARIÈS apud GORER, 1979, p.285)

Assim nasce a "bela morte” romântica: camuflar os horrores, apagar os traços de sofrimento, sumir até com os vestígios dos corpos, dos mortos. O que vê quem está vivo se não aquilo que traz as marcas de seus mortos? E o que acontece com ele quando se confronta com a negação da morte?

O sociólogo inglês mostra que a morte tornou-se tão vergonhosa e proibida quanto o sexo na época vitoriana. Uma proibição articula-se a outra, modela os comportamentos, enrijece os modos de pensamento e permite o controle e a repressão das condutas sexuais e "mórbidas". Totens e tabus, a morte e o sexo tornam-se, no apogeu da ideologia burguesa, os eixos segundo os quais podemos classificar os desviantes, ou os "anormais". ${ }^{1}$

Segundo Gorer e Ariès, a fonte da censura sobre a morte e o sofrimento por ela provocado é a mesma dos mecanismos que atuam na repressão da sexualidade.

"Hoje, a morte e o luto são tratados com o mesmo recato que as pulsões sexuais o foram, há um século (...) Atualmente, admitimos como sendo normal que os homens e as mulheres sensíveis e razoáveis possam dominar-se perfeitamente, durante seus lutos, pela força de vontade e por seu caráter. Eles não têm mais necessidade de manifestá-los publicamente; no máximo é tolerado que eles o façam privada e furtivamente, como um equivalente da masturbação.” (GORER, 1965, p.26)

Assim, o que Gorer propõe - e que é retomado por Ariès — é que a imagem do enlutado solitário e aflito é parte integrante da supressão do luto e do desaparecimento social da visibilidade da morte: "Eu sustento que o trabalho do luto é favorecido ou entravado, e sua evolução facilitada ou tornada perigosa de acordo com a forma como a sociedade em geral trata o enlutado" (idem, p.168).

Esse isolamento no qual o trabalho do luto se realiza é, para Ariès, o obstáculo, fruto de uma sensibilidade romântica, contra o qual se debateu o século $\mathrm{XX}$ no que tange ao luto, à morte e à sua visibilidade.

“Sem querer, os psicólogos fizeram de suas análises do luto um documento histórico, um atestado da relatividade histórica. A tese deles é que a morte de um ente querido é um dilaceramento profundo que, no entanto, cura-se naturalmente, desde que não se impeça a sua cicatrização. O que nos interessa é que nossos psicólogos

\footnotetext{
${ }^{1}$ Cf. o extraordinário curso de M. Foucault, Les Anormaux (1974-1975). Paris: SeuilGallimard, 1999.
} 
descrevem o luto como sendo, desde sempre, um fato natural, parte da natureza humana. A morte sempre provocaria nas pessoas mais próximas um trauma que só uma série de etapas permitiria curar. Caberia à sociedade ajudar o enlutado a ultrapassar essas etapas, porque ele não tem força para fazê-lo sozinho. Mas esse modelo que parece, aos psicólogos, ser parte da natureza humana, remonta somente ao século XVIII; o estado ao qual eles se referem não é um estado de natureza e data somente do século XIX. Antes do século XVIII o modelo era diferente e é este que, se quiséssemos, poderia, pela sua durabilidade milenar e sua imobilidade, ser aproximado de um estado de natureza." (ARIÈS, 1979, p.290)

O medo do cadáver anuncia a sua supressão. ${ }^{2}$ Sobre o cadáver jogou-se um véu e o olhar foi excluído. Ver o morto, tal seria a experiência do luto, é algo que precisa ser vivido; é a condição que possibilitaria dar ao irrepresentável um estatuto de discurso. Mas o que é ver o morto? Em que condição sabemos que vimos o morto?

A sensibilidade romântica à dor jogou um véu pudico sobre a experiência de ver o morto, sobre o desejo de vê-lo. Uma vez a morte erigida em ícone, a imagem se imobiliza porque não emociona mais. É a ideia da morte que emociona. É no intelecto que a ideia da morte se fixa. Nada do corpo é atravessado. Eu insisto na articulação entre o corpo, a imagem e os processos de pensamento que Freud propõe em seu texto O tratamento psíquico (1895) Fora desta articulação, o enlutado conserva em si a imagem imobilizada do morto.

De certa maneira, que poderia parecer paradoxal, a imagem do morto como ícone é o irrepresentável da sua morte. O movimento psíquico para no limiar desta visão, que é, de fato, o insuportável psíquico do representável. O ícone é um suporte fixo da representação, uma imagem sem sombra, sem movimento.

"Compreendemos, assim, o que se passa diante de nossos olhos. Por bem ou por mal, fomos todos transformados pela grande revolução romântica do sentimento. Ela criou, entre nós e os outros, laços cuja ruptura nos parece impensável e intolerável. É essa primeira geração romântica que, pela primeira vez, recusa a morte. Ela exaltou-a, hipostasiou-a e, ao mesmo tempo, ela fez do ser amado — não do desconhecido, não de todo mundo - um imortal inseparável.

Essa ligação ainda perdura, apesar de certa aparência de relaxamento, devido, sobretudo, a uma linguagem mais discreta, com mais pudor (...) E ao mesmo tempo, por outras razões, a sociedade não suporta mais a visão das coisas ligadas

\footnotetext{
${ }^{2}$ Frente à recusa contemporânea da morte, Philippe Ariès falou da "morte que se tornou selvagem".
} 
à morte - e, consequentemente, daquelas referentes ao corpo do morto e àqueles que o choram.” (ARIÈS, p.292)

A experiência do luto é uma experiência do visível, da (-)patia, e da catarse, retomando as coordenadas aristotélicas comentadas por Marie-José Mondzarin: “Consequentemente, para estimular o intelecto é preciso que haja desejo, e, da mesma forma, para estimular o outro, é preciso dirigir-se a seu desejo." (MONDZAIN, 2003, p.117).

"Quem fala purgação diz expulsão de um dejeto fecal, e parece improvável que Aristóteles considere as paixões como algo a ser descartado, ainda mais através do uso repentino de uma palavra tirada do vocabulário médico, sem que seu uso metafórico seja esclarecido. Como imaginar, neste caso, que ele tenha considerado a paixão como motor do julgamento? É que com o uso da palavra katharsis, no sentido do efeito de euforia provocada pela arte, perdemos toda a força da expressão perainein katharsin. Aristóteles não diz katharein, ele não utiliza o verbo, mas associa a operação catártica a um outro verbo que significa 'atravessar de lado a lado, percorrer até o fim’. Esse termo parece, de fato, próximo do alemão Durcharbeiten, que os tradutores de Freud interpretaram como perlaborar (...) A natureza da katharsis é visual." (idem, p.119)

A operação catártica consiste em ser atravessado de lado a lado. Ela permite a perlaboração do sofrimento e do traumatismo. Não nos desfazemos da dor, do tormento provocado pela morte do outro, unicamente por um efeito de discurso, o elaboramos pela visão e pela palavra, pelo olhar e pela voz. A palavra é catártica quando ela atravessa o corpo. Ora, as condições que tornam possível essa travessia do corpo são dadas pela visão. Uma imagem que não emociona não incita. "A especificidade da imagem é emocionar, logo incitar: as imagens não dizem nada, elas fazem falar" (idem, p.27). A imagem é a articulação possível entre o corpo e a palavra. Entretanto, é a imagem do corpo que queremos esconder, é dela que queremos fazer desaparecer as imperfeições, torná-la harmônica, limpá-la de todos os resíduos e de todos os horrores da carne.

Uma vez fechada o necrotério, que permitia a contemplação de vítimas de morte violenta, sórdida, a iconografia (pintura e fotografia) passa a retratar os mortos de maneira plácida, como se falecidos de morte natural, serena, bela.

Durante a exposição 0 último retrato, no museu d'Orsay, em Paris, na primavera de 2002, pude perceber a que ponto todo o traço de violência, de erotismo, e até do cômico, tinham desaparecido na representação da morte no século XIX. 
"Geralmente, o leito de morte é arrumado para assegurar uma exposição digna e apagar os traços da agonia: o último retrato é autorizado quando tudo está em ordem (...) a morte deve ser bela... Quando a morte foi acidental ou criminosa, a transferência para um leito bem feito, entre lençóis, minimiza as circunstâncias da morte."3

Vejamos um exemplo emblemático da ação do recalque sobre o caráter erótico da morte.

“Durante a sua viagem à Itália em 1834, Paul Delaroche conhece Louise Vernet, filha do pintor Horace Vernet, então diretor da Villa Medicis. Eles se casam e Louise morre dez anos mais tarde, com 31 anos. Louco de dor (nos diz o catálogo), seu marido a pinta sobre seu leito de morte, a cabeça virada para trás, os cabelos desgrenhados, a boca entreaberta, a pele emaciada e o peito coberto, com os ombros magnificamente desnudos."

Posso acrescentar os olhos semicerrados, as pupilas viradas para trás, o peito oculto por uma imensa cabeleira que cobre o corpo como um véu. O corpo cobrindo o corpo.

“Imagem ambígua (continua o catálogo), inspirada em referências do barroco romano - pensamos em Caravaggio e sobretudo no Êxtase de Santa Teresa, de Bernini - em que Eros e Tânatos se misturam: podemos ver nesta imagem a morte, mas também o orgasmo. ${ }^{5}$ É, sem dúvida, para disfarçar o caráter íntimo desta obra que o pintor acrescenta uma auréola, transformando sua mulher numa santa." 6

Para mim, não se trata verdadeiramente de um “disfarce”: seria preciso uma ingenuidade suspeita, ou uma extraordinária negação da parte do expectador para deixar-se "confundir" por esta auréola que, neste gesto negativo, “acusa” o traço erótico do corpo. "Não, espectador, não pense que eu quis erotizar a morte da minha mulher. Veja, há até uma auréola, é uma santa”... "Não pense, sobretudo, que se trata da minha mãe!"7 De tanto querer retirar o erotismo, a violência e o cômico da representação da morte, do corpo morto, eles retornam

\footnotetext{
${ }^{3}$ Le dernier portrait, catálogo da exposição, Paris: Édicion de la Réunion des Musées Nationaux, 2002, p.40.

${ }^{4}$ Ibidem.

${ }^{5}$ Nota do tradutor: em francês, "petite mort".

${ }^{6}$ Idem, p. 62.

${ }^{7}$ Cf. esse é o paciente que Freud evoca no seu artigo “A negação” (1925).
} 
- neste caso sob o traço da auréola, que tem, para mim, a função de um chiste inconsciente do autor.

Assim, a bela morte asseptizada, livre de seus maus cheiros, de suas últimas palavras cômicas e da violência, passa a ocupar, no final do século XIX, o espaço coletivo e ritual, esvaziando-o das ferocidades e lascívias relativas ao morto.

$\mathrm{Na}$ descrição que Flaubert faz do falecimento de Ema, em Madame Bovary, as imagens da morte mantêm vivas uma iconografia recalcada, "aureolada". O processo de censura contra o livro é emblemático da repressão da sociedade sobre a representação da morte, a ponto do grande poeta romântico francês, Lamartine, dizer a Flaubert: "Você me fez mal, você me fez literalmente sofrer! A expiação é desproporcional ao crime; você criou uma morte atroz, espantosa (...) é um suplício como jamais tínhamos visto. Você foi longe demais, você me fez mal aos nervos."

Extraordinária confissão do mais romântico dos poetas franceses, que não pôde suportar nem a imagem, nem a exposição do corpo da morta criadas por Flaubert. A violência, o erotismo e a comicidade desta exposição da morte a tornam uma passagem audaciosa da literatura e são uma das razões pelas quais Proust tanto amava Madame Bovary.

“Ema tinha a cabeça pendida para o ombro direito. O canto da boca, que conservava aberta, parecia um buraco negro escuro na parte inferior do rosto; os dois polegares permaneciam dobrados para a palma das mãos; cobria-lhes as pestanas uma espécie de poeira branca e os olhos começavam a desaparecer numa lividez viscosa, que se assemelhava a um tecido tênue, como se neles lhe tivessem as aranhas feito uma teia. O lençol desenhava-lhe o corpo desde o seio até os joelhos, erguendo-se depois na ponta dos pés; e a Carlos afigurava-se que pesavam sobre ela massas infinitas, um peso enorme.

Felicidade soluçava:

- Ah! Minha pobre patroa! Minha pobre patroa!

— Olhe, como está bonita ainda! — dizia, suspirando, a estalajadeira. — Dirse-ia que vai levantar-se, de uma hora para outra.

Depois, inclinaram-se sobre ela, para lhe porem a grinalda. Foi preciso erguerlhe um pouco a cabeça e então saiu-lhe da boca, como um vômito, uma onda de líquido negro.

— Ah! meu Deus! — exclamou a Sra. Lefrançois. — Tome cuidado com o vestido. Ajude-nos aqui! — disse ela ao farmacêutico. Estará com medo, por acaso?

- Medo, eu? - replicou ele, encolhendo os ombros. — Que ideia! Vi muito pior do que isto no hospital, quando estudava farmácia. Nós até fazíamos ponche no anfiteatro das dissecações, pois não há nada que espante um filósofo e até, já o 
tenho dito muitas vezes, é minha intenção legar o meu corpo aos hospitais, a fim de servir mais tarde à ciência." (FLAUBERT, 1970)

Nesta cena da morte de Ema, ao misturar a violência do cadáver vomitando com o cômico da tolice de Homais, Flaubert degrada o espírito da bela morte romântica.

Como se não bastasse, há ainda Carlos Bovary, que Flaubert erige ao ranking de cômico da situação, não sem alguma provocação à moral burguesa. A morte provoca em Carlos sensações, tanto de horror misturado de curiosidade, como de excitação sexual.

“Carlos (...) vinha fazer suas despedidas.(...) A cera dos círios cobria de grandes pingos os lençóis da cama.(...) Viam-se tremular clarões no vestido de cetim, branco como o luar. (...) Demorou-se muito tempo a recordar-se de todas as felicidades perdidas, das suas atitudes, dos seus gestos, do timbre da sua voz." (Idem, p. 248 a 249)

Flaubert descreve a seguir cenas jocosas, leves, cheias de frescor, que evocam os pensamentos de Carlos, como se quisesse acusá-lo de lembrar-se, de uma forma devota e banal, de um cotidiano açucarado, livre de todo erotismo, mas tingido pelo imaginário tacanho do pequeno burguês provinciano.

“Depois, de repente, via-a no jardim de Tostes, sentada no banco, encostada à sebe de silvas, ou, então, nas ruas de Ruão, à porta da sua casa (...) Ouvia ainda os rapazinhos rindo e dançando debaixo das macieiras; o quarto estava cheio do perfume dos seus cabelos e o vestido, estremecia-lhe nos braços com um rumor de fagulhas. Era a mesma, aquela!” (idem, p.249, grifos nossos)

A evocação poderia ser a de um sonho de Carlos. Sonho, lugar de todas as imagem proibidas, imagens cujo movimento escava o leito do luto.

A ironia de Flaubert acerca do estilo rebuscado do romantismo aparece no final do parágrafo. O retorno do recalcado está na frase curta, que tem função de chiste. A lembrança aureolada da Ema rodopiante, bela, perfumada, que age sobre a melancolia do romântico Lamartine, é ridicularizada (escutemos os risos) e encenada de forma cômica no final do parágrafo: "era a mesma, aquela!" e o cadáver, cujas entranhas apodreciam, vomitando um jato negro sobre o vestido.

Da mesma forma, dois parágrafos adiante, depois dessas lembranças pueris, lemos que Carlos “teve uma curiosidade terrível: lentamente, com a ponta dos 
dedos, levantou-lhe, palpitante, o véu; mas soltou um grito de horror, que despertou os outros dois."

A forma estilística usada por Flaubert, neste trecho, é emblemática de uma encenação mascarada. O cadáver está coberto por um véu, e no ato de descobri-lo, sem o uso de uma única palavra, Flaubert nos mostra o afeto de Carlos Bovary. Ele utiliza a elipse como figura de estilo, quer dizer, faz uso de um recurso estilístico que descentraliza o objeto, que expõe a imagem ao afeto. A elipse é a figura de estilo da máscara: ela expõe, sugere, libera imagens, exibe uma ausência. ${ }^{8}$

A elipse é aparecimento, no fluxo da linguagem, de uma expressão concisa que remete a um sentido implícito: "ele levantou o véu. Mas deu um grito de horror". Entre as duas proposições, existe uma ausência de palavras que permite ao leitor tornar presente, na sua própria linguagem, a imagem do corpo.

Ao sugerir em vez de demonstrar, a elipse cria uma conivência com o imaginário, permitindo-lhe uma abertura. Ela estabelece uma ruptura entre dois termos, ou entre um grupo de termos. Essa ruptura é uma falta, não um vazio, como nos mostra, inclusive, sua etimologia grega. Ela revela o que está enterrado.

A elipse engendra, supõe ou revela uma profundidade, uma espessura de sentido mascarada pela superfície lisa e ordenada do explícito e das unidades lexicais, que ela abandona aos dicionários. Labirinto do inconsciente, novo paradigma ou sistema, outra visão do mundo: brincando e rompendo a máscara, a elipse descortina uma dimensão que, mesmo sempre tendo estado em jogo, estava até então eclipsada.

A elipse é uma forma retórica que expõe sem palavras, ela pertence ao campo da imagem, do afeto e do sintoma.

Flaubert encobre a visão do leitor, mas nesse processo ele revela a putrefação do cadáver de Ema. É através do sentimento de Carlos que o leitor vê Ema. É, também, através dele que lhe é permitido ver o que o narrador lhe oculta. O analista poderia ver através do afeto o que o inconsciente oculta ao analisando?

Para concluir sobre a morte de Ema Bovary, Flaubert, por meio de outra figura de estilo mascarada, erotiza o desejo "necrófilo” de Carlos.

Carlos Bovary acaba de descobrir as cartas dos amantes de Ema, precisamente, as de Rodolfo. Longe de ser tomado por um ciúme ambivalente ("seu ciúme

\footnotetext{
${ }^{8}$ Elipse (etimologia: do latim ellipsis, do grego elleipsis, “falta”. De elleipseine, "deixar de lado”). Segundo o dicionário Robert, é uma figura retórica, um procedimento discursivo que consiste na não expressão de uma ou várias palavras que o espírito deve suprir. A elipse pode ocorrer tanto numa imagem quanto numa forma da linguagem. A elipse intervém na formação de certas palavras e expressões (abreviação: "cit”). Elipse do sujeito (faças o que deves), do verbo (para quando a sua visita?), do sujeito e do verbo, ao mesmo tempo (longe dos olhos, longe do coração).
} 
incerto perdeu-se na imensidão de sua tristeza”), ele se deixa levar por uma fantasia plena de desejo:

“'Não podiam deixar de adorá-la', pensava. 'Todos os homens, com certeza, a tinham cobiçado'. Ema pareceu-lhe ainda mais bela; e concebeu um desejo permanente, furioso, que lhe inflamava o desespero, e que não tinha limites, porque já era irrealizável.

Para lhe agradar, como se ela vivesse ainda, adotou suas predileções, as suas ideias; comprou botas de verniz e passou a usar gravatas brancas. Punha cosméticos no bigode. (...) Ema corrompia-o do além túmulo. (...)

Coisa estranha é que Bovary, pensando continuamente em Ema, ia-se esquecendo dela e desesperava-se vendo como a imagem se lhe apagava da memória, apesar dos esforços que fazia para a reter.

Ainda assim, todas as noites sonhava com ela; aproximava-se-lhe, mas, quando ia abraçá-la, desfazia-se-lhe em podridão nos braços.” (Ibidem)

Flaubert insiste: durante o enterro de Ema, no momento mesmo em que cada um a transforma, para sempre, em lembrança, o corpo podre de Ema torna-se o sepulcro psíquico de Carlos. Nenhuma concessão à bela morte, dolorosa e romântica: a lembrança de Ema é, no inconsciente de Carlos, um corpo putrefato, e é este corpo putrefato de Ema que, do além-túmulo, “corrompe” Carlos.

Compreendemos que essas imagens tenham chocado a moralidade da época e que, em decorrência, o requisitório do processo contra a obra tenha sido de grande violência. O caráter lascivo, voluptuoso, o elogio ao adultério e a crítica à religião tiveram papel fundamental no processo, mas entre os principais pontos da acusação encontram-se a morte e a maneira pela qual ela é tratada por Flaubert.

Trecho extraído do processo:

"um dia ele abre sua escrivaninha e encontra o retrato de Rodolfo, suas carta e as de Leon. Vocês pensam, que neste momento, o amor acaba? Não, não, ao contrário; ele se excita, ele se exalta por essa mulher que outros possuíram, devido a essas lembranças voluptuosas que ela lhe deixou; e a partir deste momento ele negligencia a sua clientela, sua família. Ele desperdiça, jogando aos quatro ventos as últimas parcelas do seu patrimônio, e um dia ele é encontrado morto no caramanchão do seu jardim, segurando nas mãos uma longa mecha de cabelos negros." (idem, p.423, grifos nossos)

Não apenas Carlos é corrompido do além-túmulo, pior: ele "se excita” por uma morta que ele fetichiza e de quem guarda relíquias. 
“E, uma vez o corpo frio, é preciso respeitar acima de tudo o cadáver que a alma deixou. No trecho em que o marido está lá, ajoelhado, chorando sua esposa, depois de ter estendido o sudário sobre ela, qualquer outra pessoa teria interrompido o relato, porém o senhor Flaubert termina: 'O lençol desenhava-lhe o corpo desde o seio até os joelhos, erguendo-se depois na ponta dos pés."'

Depois da citação, ele retoma o requisitório: “Eis a cena da morte. De certa forma, eu a resumi, a reagrupei. Cabe aos senhores julgarem e apreciarem se estamos diante de uma mistura do sagrado com o profano, ou se não seria, antes, a mistura do sagrado com o voluptuoso" (grifos nossos)

E o requisitório segue, no mesmo estilo, na tentativa de convencer o tribunal de que o "gênero do senhor Flaubert é um gênero lascivo, voluptuoso, ultrajante". Ultraje quer dizer que passa dos limites. De qual limite? O do afeto, do nominável e do desejo. A imagem do corpo é, neste caso, uma fábrica de desejos, e mostrá-la é ultrapassar o limite. É precisamente esse limite que traça a moral burguesa do século XIX a propósito da morte e da sexualidade. O que condena o requisitório é o "ultraje" (na acepção de "passar dos limites”, como Lacan utiliza em sua referência a Antígona) que faz vacilar o ser, o faz ultrapassar obstáculos, ir mais além (l’hybris).

A condenação de Madame Bovary aconteceu em 1857, alguns anos antes do começo da campanha pelo fechamento da Morgue. ${ }^{9}$ Momento no qual a ideologia do recalque está, pouco a pouco, encobrindo as evocações violentas, eróticas e cômicas da morte e do corpo do morto.

A carne, a encarnação do corpo, não a pura lembrança, mas seu cerne que é a pulsionalidade do fantasma, são reprimidos de maneira manifesta e radical. Tudo se passa como se o recalcamento da evocação da morte deixasse vivas, pulsionais e ativas a erotização e a violência da situação.

"O que chamamos, atualmente, a boa morte, a bela morte corresponde exatamente ao que, antigamente, considerava-se uma morte maldita, la mors repentita et improvisa, que passava despercebida. 'Ele morreu esta noite, enquanto dormia: não mais despertou. Ele teve a morte mais bela que existe.” (ARIÈS, 1979, p.297)

\footnotetext{
${ }^{9}$ Nota do tradutor: no século XVIII, funcionou em Paris uma morgue, ou necrotério. Em 1868, ela ganha um novo prédio com ares de um pequeno templo grego, arquitetura do barão Haussmann. Nesta época, visitar a Morgue era um dos passeios mais na moda em Paris. Os cadáveres a serem identificados (sobretudo vítimas de afogamento) ficavam expostos por três dias, deitados em 12 mesas inclinadas, feitas de mármore preto, numa sala separada do público por um vidro.
} 
Essa "morte que passa despercebida”, sobrevive atualmente de forma ativa; o mais distante, o mais violento, o mais pulsional não podem passar despercebidos. Essa morte dissimulada, digna, silenciosa, virtuosa faz do enlutado um "vivo que passa despercebido".

O papel do analista, na elaboração do luto, não seria o de criar, pela e na transferência, as condições de possibilidade da fabricação de imagens que emocionem, dando assim, mobilidade a vida psíquica para que o enlutado seja afetado pela imagem e aceda a palavra erótica, violenta e cômica do luto?

Liberar a imagem à possibilidade de ver. De ver como ato de conhecimento. Toda a imagem é um retorno a si mesmo.

O trabalho do luto torna-se o trabalho de sobrevivência, de que fala DidiHuberman à partir de sua leitura de Aby Warburg. Sobrevivência do recalcado, de movimentos psíquicos que agem como fósseis em movimento.

O mais recalcado é o mais persistente, o mais antigo é o mais ativo, o mais morto é o mais vivo. O que sobreviveu retorna em todas as formas e conteúdos pelas forças da imagem em movimento.

O processo de identificação é um processo de mão dupla: não é apenas o sujeito que se identifica ao objeto, mas o objeto, também, identifica o sujeito. A identificação se faz, ainda, pelo olhar de quem me olha. São com essas identificações em movimento que trabalha a operação de ver. É o desdobramento de um olhar que, para ir além das aparências, deve ser captado em um reflexo. Não é somente o espectador que olha o objeto, ele é também olhado pelo objeto, no caso, o cadáver. Este seria o ponto de emergência da angústia: "O que é percebido, por muitas pessoas, como sendo capaz de provocar, no mais alto grau, uma sensação de estranheza inquietante são as coisas relacionadas à morte e aos cadáveres, ao retorno dos mortos, aos espíritos e aos fantasmas" (FREUD, 1919, p.246).

É a experiência da semelhança, ou melhor, do que aparece ao olhar como semelhante, que cria a inquietante estranheza daquilo que sobreviveu, quer dizer, que dá a condição de possibilidade da sua intrusão no espaço psíquico.

A violência da imagem tornaria acessível um espaço psíquico que através angústia liberaria o fantasma. Um dos aspectos da experiência analítica do luto seria essa experiência de violência, no sentido de que a aparição de figuras, de formas, poria em movimento aspectos da vida psíquica, que e a defesa, por meio da clivagem, teria fixado.

Tratar-se-ia, nesse retorno das formas, de deslocar as linhas de fratura, como se um terremoto movimentasse as placas tectônicas separando os continentes, cujos recortes se encaixariam perfeitamente. 
"A luta com a sombra é a única luta real. No momento em que a sensação visual afronta a força invisível que a condiciona, ela desobstrui uma força capaz de vencer aquela, ou bem de fazer dela uma amiga. A vida grita para a morte, mas justamente a morte não é mais esse visível-demais que nos faz desfalecer, ela é essa força invisível que a vida detecta, descobre e deixa ver gritando. É da perspectiva da vida que julgamos a morte, e não o inverso onde nós nos satisfazemos." (DELEUZE, 1981, p.42)

E Deleuze cita Bacon: "se a vida vos excita, a morte, seu oposto, como uma sombra, deve vos excitar" ibidem. Acolher a excitação na vida como na morte.

O ato de ver é violento porque sua plasticidade obriga a abertura de novas vias. A imagem vista modifica a forma de ver. É o que Bacon desenvolve quando utiliza os termos "romper para ver”, uma violência que conduz a outra coisa. Essa violência comporta o traço da hostilidade, tal como Warburg (1923) o designava: "Podemos supor que a obra de arte é uma coisa hostil que se movimenta em direção do espectador." Encontramos nessa ideia, a concepção de que o ato de ver não é um fato que depende somente de quem olha, implica também o que emana do que vemos. Reencontramos as ideias desenvolvidas acima, do reflexo e de "receber e rejeitar". De fato, a palavra 'hostil' tem essa estranha configuração semântica, ela significa ao mesmo tempo "o hospedeiro que recebe" e "aquele que rejeita”.

Ver o morto pelo prisma da forma alucinada do fantasma põe em jogo de maneira radical a posição do sujeito na experiência visual. Segundo Didi-Huberman (2000), para aceder à experiência da visão, é preciso que a imagem seja 'fratura'. Tanto no sonho como num momento de despersonalização, a visão do morto fratura o olhar em dois. É a “diabolie” do olhar: eu vejo e não reconheço. Tem uma presença e uma ausência. O que aparece ao olhar é fruto de uma deformação (à semelhança do trabalho do sonho).

A paciente que diz ter medo de tornar-se louca, vê se formar pela deformação da alucinação a aparição de um sintoma. Podemos conceber a "imagem-fratura" como uma formação do inconsciente dada a deformação que ela apresenta, que ela põe em cena. Trata-se, através da imagem, de "propor" ao expectador as condições de possibilidade de uma "cisão" que descentra o sujeito e dá acesso ao inconsciente, à formação de sintoma.

$\mathrm{Na}$ experiência analítica, a questão da angústia encontra-se no centro da “imagem-fratura”. São as questões freudianas da inquietante estranheza e do duplo, experiências nas quais vemos o outro em sua forma primitiva.

Tudo se passa como se a experiência da "imagem-fratura" fosse a experiência própria da angústia. O que o retrato nos mostra não é o tempo da história 
cronológica, mas a história como incessante anacronismo. A “imagem-fratura” é a figurabilidade do anacronismo.

“As imagens só conservam sua força ativa se as consideramos como fragmentos dissolvendo-se enquanto agem, ou deterioram-se rapidamente, à semelhança de organismos vivos, frágeis e mortais. Elas só possuem um sentido se as consideramos como centro ativo da energia e lugar de cruzamento de experiências decisivas. As obras de arte só adquirem seu verdadeiro sentido graças à força de insurreição que contêm.” (DIDI-HUBERMAN apud EINSTEIN, 2000, p.17)

Imagens que se dissolvem ao mesmo tempo em que agem, não é precisamente o que ocorre com obra imaginal do sonho, composta de imagem plásticas e dialéticas? Os retratos de cera, as máscaras mortuárias seriam o que existe de mais próximo dessa dialética da imagem. Criam o descentramento necessário ao olhar, pelo campo de profundezas que geram, pela inquietude, pela angústia e mal-estar. O acesso ao inconsciente se faria por esse descentramento que desnudaria a imagem e a deslocaria no espaço e no tempo.

Aboliu-se toda a representação do espetáculo da morte, dessa "pornografia da morte". O que era um modo social de figuração da morte foi reprimido e como consequência o movimento imaginário que proporciona a narração, fixouse numa imagem. Tudo se passa como se o corpo real tivesse sido excluído da imagem do morto. A nudez e o horror misturados à fascinação abrem a uma crueldade do olhar que por efração permite o movimento da imagem.

"As imagens orgânicas teriam duas faces. Alberti sugere-o afirmando que o corpo aberto, esfolado, é para um corpo nu o que este é para um corpo coberto. Goethe, por sua vez, sugere o mesmo afirmando que a parte interna do organismo aparece na natureza exterior 'eternamente mutável' do seu envelope visível.

Tais proposições são ao mesmo tempo evidentes e difíceis de serem apreendidas em todas as suas implicações: o interior pode ser pensado como a estrutura subjacente - o esqueleto, em primeiro lugar, o imutável, que dá ao conjunto do corpo sua lei física de harmonia; neste sentido, o interior assegura a função de esquema, quer dizer, o poder mesmo da forma (...) Mais uma vez, somos obrigados a pensar juntos, mas sem esperança de um dia unificá-los, a harmonia e a beleza de um lado, e a efração e a crueldade de outro. Toda a questão da nudez parece suspensa nesta dialética. Estrutura ou ferida? Forma ou informe? Conformidade ou conflito." (DIDI-HUBERMAN, 1999, p.41)

"Imagens de duas faces", como as que aparecem ao sonhador; de duas faces, ou mesmo, de múltiplas faces, cujas anamorfoses significantes são tantas quantas 
as palavras possíveis, tantos elos para recompor uma posição subjetiva atingida por um traumatismo. Atingida na sua constituição imaginária, na medida em que ela perdeu algo do morto que ela desconhece, o enlutado faz assim um trabalho de reconstituição das imagens internas. O trauma rompeu o espelho constitutivo da imagem de si e embaralhou o reflexo do enlutado, será necessário o reencontro do semelhante para reinvestir o que está vivo. Semelhante que possa fazer emergir o movimento psíquico. Emocionar para incitar. A angústia permite o surgimento do movimento.

Para praticar a crueldade do olhar, Didi-Huberman propõe que vejamos os nus harmoniosos de Botticelli. As polaridades estão contidas numa mesma estrutura: os nus horripilantes dos cadáveres expostos convocam uma polaridade harmoniosa, uma forma estética “do grito” mais do que a do horror.

O grito encontra-se no que desconhecemos do horror e da fascinação, da beleza e da crueldade. Razão pela qual a imagem-movimento do morto se inscreve, segundo minha opinião, num entre-dois, no espaço do grito e do inarticulado, entre a imagem e a palavra. A representação (mas a palavra representação seria ainda adequada?) do morto, seja ela: no ritual, na forma imaginada, ou na forma real do cadáver provém de uma experiência do olhar que dilacera um espaço visual próprio. Um espaço, como eu já disse, limítrofe, de travessia, de passagem. Travessia das aparências se seguirmos as lições de Starobinski: "O olhar prendese dificilmente à pura constatação das aparências (...) ele abre caminho a um tipo de impulso que não é mais interrompido. Falar: inteligência, crueldade, ternura é dizer pouco. Elas não são apaziguadas, saciadas" (STAROBINKI, 1994, p.10-11).

Travessia das aparências, pela e na pulsão que não se interrompe, tal é o objetivo de uma encenação da morte, um espaço intermediário no qual sentimos "o sopro indistinto da imagem". ${ }^{10}$ A pulsionalidade do olhar abre a um tempo libidinal no qual o pensamento é novamente possível, ele é de novo mobilizado pela vida psíquica.

Essa violência, essa hostilidade que "vai" na direção de quem olha é, na minha opinião, a experiência mesma do exercício da crueldade que representa o trabalho do luto. Os rituais africanos, as paradas romanas em grande pompa, as exposições de cadáveres participam dessa hostilidade. Eles são a abertura de um caminho necessário para que a imagem não se fixe, para que sejam postas novamente em circuito identificações móveis. Algo se quebra no lugar aonde olhamos.

Recebido em 10/6/2011. Aprovado em 24/3/2012.

\footnotetext{
${ }^{10}$ Segundo a expressão de Pierre Fedida, "Le souffle indistinct de l'image", in La Part de l'œil, n.9, Arts plastiques et psychanalyse II, 1993.
} 


\section{REFERÊNCIAS}

ARIÈS, Philippe. (1979) L'homme devant la mort. Paris: Seuil.

DELEUZE, Gilles. (1981) Francis Bacon: Logique de la sensation, Paris: Différence.

DIDI-HUBERMAN, Georges. (2000) Devant le temps, Paris: Minuit. (1999) Ouvrir Vénus, Nudité, rêve, cruauté. Paris: Gallimard.

FEDIDA, Pierre (1993) Le souffle indistinct de l'image, La Part de l'œil, n.9, Arts plastiques et psychanalyse II.

FLAUBERT, G. (1970) Madame de Bovary. São Paulo: Abril Cultural. (Os Imortais da Literatura Universal, v.3).

FOUCAULT, M. (1974-75/1999) Les Anormaux. Paris: Seuil-Gallimard.

FREUD, Sigmund.(1919/1985) “L’inquiétante étrangeté”, in: L’inquiétante étrangeté et autres essais. Paris: Gallimard, p.209-264.

. (1925/1985) “La négation”, in: Résultats, idées, problèmes II. Paris:

PUF, p.135-137.

GORER, Geoffrey. (1965/1995) Ni pleurs, ni couronnes, Paris: Epel.

MONDZAIN, Marie-José. (2003) Le commerce des regards, Paris: Seuil.

STAROBINKI, J. (1994) L'œil vivant. Paris: Gallimard.

Laurie Laufer

laurie.laufer@wanadoo.fr

Roberta Bertone

robertabertone7@gmail.com 